\title{
The neuro-ophthalmology of HIV-AIDS review of Neurobehavioral HIV Medicine
}

This article was published in the following Dove Press journal:

Neurobehavioral HIV Medicine

17 September 2012

Number of times this article has been viewed

\author{
Padmaja Sudhakar ${ }^{\prime}$ \\ Sachin Kedar ${ }^{1,2}$ \\ Joseph R Berger ${ }^{1,3}$ \\ 'Departments of Neurology, \\ University of Kentucky College \\ of Medicine, Lexington, KY, USA; \\ ${ }^{2}$ Departments of Ophthalmology, \\ University of Kentucky College \\ of Medicine, Lexington, KY, USA; \\ ${ }^{3}$ Departments of Internal Medicine, \\ University of Kentucky College of \\ Medicine, Lexington, KY, USA
}

Correspondence: Sachin Kedar Department of Neurology L445 Kentucky Clinic, 740 South Limestone Street, Lexington, KY 40536-0284, USA

Tel 859-2। 8-5035

Fax 859-323-5943

Email sachinkedar@uky.edu

\begin{abstract}
Neuro-ophthalmic problems are known to occur both in human immunodeficiency virus (HIV) infection and AIDS. Central nervous system (CNS) opportunistic infections and malignancies such as lymphoma are the major source of these problems but some result from the direct effect of the virus on the CNS. Both the afferent visual pathway and efferent ocular motor system may be affected. Neuro-ophthalmic signs may sometimes be the initial manifestation of AIDS. A variety of neuro-ophthalmic manifestations may be encountered in the same patient. Several large studies on the ophthalmic features of AIDS have included neuroophthalmic manifestations in their series. However dedicated comprehensive review articles on this subject are few. Despite the introduction of highly active antiretroviral therapy (HAART), neuro-ophthalmic manifestations still remain a problem in HIV. The aim of this article is to provide an overview of the neuro-ophthalmic sequelae of AIDS.
\end{abstract}

Keywords: HIV, AIDS, ophthalmology, eye, pupil, cranial nerve, ocular motility, visual loss

\section{Introduction}

HIV/AIDS is a global pandemic with cases described in almost every country in the world. AIDS was first recognized as a clinical entity in $1981^{1}$ and the etiologic agent, the human immunodeficiency virus (HIV), a cytopathic retrovirus was first identified in $1983 .^{2}$

HIV, a neurotrophic virus enters the CNS in the early stages of infection and invades mainly the microglia and macrophages, and rarely the neurons. HIV/AIDS can produce neurological and neuro-ophthalmic abnormalities either as a direct effect of the virus on the nervous tissue or indirectly through opportunistic infections and malignancy resulting from the immunodeficiency. The prevalence of neurological disease in symptomatic HIV infected patients is estimated to be $39 \%-70 \% .^{3-5}$ HAART has largely changed the incidence and prognosis of HIV associated neurological disorders in the developed countries, ${ }^{6}$ but this may not be the case in developing countries. ${ }^{7}$

Ocular manifestations of HIV/AIDS were first reported in $1982 .{ }^{8}$ About $50 \%-75 \%$ of patients infected with HIV will develop ocular manifestations with a cumulative lifetime rate of developing at least one ocular lesion of $52 \%-100 \%$. ${ }^{9}, 10$ The neuroophthalmological manifestations result from involvement of the afferent visual pathways, the efferent ocular motor, the pupillary system, and the visual centers in the brain. Not infrequently, neuro-ophthalmic manifestations may be a presenting feature of HIV infection.

Given an extensive body of literature on the subject, we hope to provide a summary of the varied neuro-ophthalmic manifestations resulting from HIV/AIDS. 


\section{Involvement of the eye and ocular adnexa}

The lesions of the anterior segment and ocular adnexa include spontaneous staphylococcus aureus eyelid ulcers with blepharitis, ${ }^{11}$ molluscum contagiosum with eyelid abscess, ${ }^{12}$ limbal epibulbar molluscum contagiosum, ${ }^{13}$ Kaposi's sarcoma, ${ }^{14-16}$ conjunctival vascular abnormalities, ${ }^{17}$ sub-conjunctival hemorrhages, chronic dacrocystitis, periorbital ecchymosis (from HIV related idiopathic thrombocytopenic purpura), episcleritis, dry eyes, keratitis (from herpes simplex virus, cytomegalovirus, and microsporidia), corneal opacity, neurotrophic corneal ulcer, zoster related keratouveitis, anterior uveitis, syphilitic uveitis, drug induced uveitis (rifabutin and cidofovir in the pre- HAART era) and complicated cataract. ${ }^{18-22}$

HIV can produce retinal microangiopathy that results in cotton wool spots, microaneurysm, intraretinal hemorrhages, white centered hemorrhages, telengiectasia and capillary non perfusion. ${ }^{18-23}$ Other posterior segment findings include choroidal infiltrates (from syphilis, toxoplasma, tuberculosis, pneumocystosis), chorioretinitis, progressive outer retinal necrosis (PORN), acute retinal necrosis (ARN), cytomegalovirus (CMV) retinitis, Bartonella henselae associated multifocal retinitis, frosted branch angitis and retinal detachment following any form of retinitis. ${ }^{24-27}$ Reticulum cell sarcoma (B cell lymphoma of the retina) can present as yellowish white retinochoroidal lesions, peripapillary infiltrates, optic disc swelling and flame shaped hemorrhages. ${ }^{28}$ Panuveitis, immune recovery uveitis (a form of immune reconstitution syndrome) and endogenous endophthalmitis have also been reported. ${ }^{18-23,29} \mathrm{CMV}$ retinitis and HIV microangiopathy are the most common ocular manifestations in AIDS both in the pre HAART and HAART era. ${ }^{30}$ The presence of retinal microangiopathy has been noted to be associated with increased risk of mortality in AIDS patients. ${ }^{30}$ The incidence and severity of CMV retinitis has become less after HAART though new cases do exist. ${ }^{29,31,32}$

Occlusion of retinal vasculature has been reported in patients with AIDS. Both microvascular and macrovascular disease may co-exist in AIDS. ${ }^{33}$ In a retrospective study of 2,484 patients with HIV, $1.3 \%$ had retinal vascular occlusion. ${ }^{34}$ While central retinal vein occlusion was the commonest occlusion in the series, other forms such as branch retinal vein occlusion, hemiretinal vein occlusion, branch retinal artery occlusion, central retinal artery occlusion, combined retinal artery and retinal vein occlusion and Purtscher like retinopathy were also reported. ${ }^{35}$ These vascular occlusions are believed to result from immune complex deposition and elevated levels of tumor necrosis factor alpha which produce a pro-thrombotic state ${ }^{36}$ Recanalization of an occluded branch retinal artery following treatment with doxycycline for Bartonella henselae retinitis, was reported in a patient with AIDS. ${ }^{26}$

\section{Neuro-ophthalmic manifestations}

The neuro-ophthalmic manifestations of HIV were described in the early years of the HIV pandemic. ${ }^{37,38}$ Neuro-ophthalmic abnormalities have been estimated to occur in $2 \%-8 \%$ of patients with AIDS. ${ }^{24,38-40}$ Other studies have reported neuro-ophthalmic abnormalities in as much as $60 \%$ of neurologically symptomatic HIV patients. ${ }^{9}$

\section{Optic neuropathy}

Optic neuropathy in patients with HIV/AIDS may result from inflammation, ischemia, infection, compression, infiltration, and increased intracranial pressure. Opportunistic infections account for the largest cause of optic nerve disease and vision loss in AIDS. Optic nerve inflammation in AIDS develops largely from opportunistic infections. However the optic nerve may be a direct site of insult of HIV. All forms of optic neuritis have been reported.

\section{Primary HIV optic neuropathy}

HIV optic neuropathy is a diagnosis of exclusion after opportunistic infections and neoplasm have been excluded. Unilateral ${ }^{18,41}$ as well as bilateral presentations have been reported. ${ }^{42-46}$ Clinically, it may present as papillitis, retrobulbar optic neuritis, or neuroretinitis. Visual loss can be variable and severe field loss may be seen. ${ }^{44}$ Optic neuritis accompanied by a relapsing remitting neurological illness (similar to multiple sclerosis) was described in the setting of seropositivity for HIV-1 infection. ${ }^{47}$

The pathogenesis of HIV optic neuropathy remains uncertain. Postmortem morphometric analysis of the optic nerves of HIV infected individuals has shown chronic degeneration and diffuse axonal loss. ${ }^{48}$ Sadun et al have demonstrated HIV DNA within the optic nerves and the retina ${ }^{49}$ of HIV infected patients which was associated with patchy axonal degeneration, oligodendrocyte and myelin degeneration and mononuclear cell infiltration. They postulated that the optic nerve degeneration was mediated by HIV infected macrophages rather than direct HIV infection of the axons. HIV infected macrophages have been shown to release cytokines particularly TNF alpha which can induce neuronal apoptosis and produce optic nerve degeneration, ${ }^{50,51}$ release IL-1B and IL-6 from astrocytes, macrophages and endothelial 
cells in the optic nerves, and may also contribute to immune mediated neuronal damage. ${ }^{52}$ It is now felt that HIV optic neuropathy may be immune mediated.

Early initiation of HAART has been shown to improve vision. ${ }^{44,53}$ A relapsing remitting course similar to multiple sclerosis and steroid responsiveness has also been described. ${ }^{54}$ High doses of pentoxifylline have been shown to suppress TNF alpha mediated optic nerve axonal degeneration experimentally. ${ }^{55}$

\section{Infectious optic neuropathy}

Optic nerve disease in patients with HIV/AIDS may present as papillitis (disc swelling), retrobulbar optic neuritis (normal optic disc appearance) or optic perineuritis (swollen optic disc with enlarged blind spot and relatively normal visual functions) or neuroretinitis (disc edema with macular exudates with star formation).

Cytomegalovirus (CMV) can involve the optic nerve during advanced stages of retinal disease ${ }^{39,56-59}$ resulting in severe visual loss. Optic nerve involvement occurs either as a primary optic nerve infection with associated peripapillary retinitis or secondarily by extension of the peripapillary retinitis to the disc margin. ${ }^{60}$ Retrobulbar optic neuritis has also been described. ${ }^{61} \mathrm{CMV}$ optic neuritis may co-exist with other opportunistic infections and lymphoma, making diagnosis difficult. On histology, CMV inclusions have been seen within all layers of the retina and within the optic nerve. ${ }^{62} \mathrm{CMV}$ optic neuritis generally carries a poor prognosis because of irreversible necrosis of the optic disc. In contrast, optic neuritis caused by an extension of the retinitis seems to respond favorably to antiviral therapy. ${ }^{60}$ Treatment includes high doses of intravenous foscarnet and/or gancyclovir ${ }^{63}$ and also with oral valgancyclovir. ${ }^{64}$ Treatment should be initiated early before the development of optic atrophy.

Toxoplasma optic neuritis can present as papillitis, retrobulbar optic neuritis and neuroretinitis often with retinochoroiditis. ${ }^{9}$ Ocular toxoplasmosis frequently presents with bilateral and multifocal involvement with vitritis. The infection is believed to result from a new infection of dissemination from a non-ocular site. ${ }^{65}$ Toxoplasma has been demonstrated within both the nerve fiber layer and ganglion cell layer. ${ }^{66}$

Herpes simplex virus (HSV) and herpes zoster virus (HZV) may produce acute retinal necrosis (ARN) and progressive outer retinal necrosis (PORN) in patients with AIDS. Optic nerve involvement in the form of disc edema, hyperemia and atrophy may be seen in both ARN and PORN ${ }^{67}$ Papillitis, retrobulbar optic neuritis ${ }^{9,68-74}$ and neuroretinitis have been reported in AIDS in association with cutaneous herpes zoster, herpes zoster ophthalmicus and aseptic meningitis. ${ }^{75}$ Optic neuritis has also been reported as the heralding event for the herpetic infection. Intravenous acyclovir is the first line of treatment for optic nerve involvement, but response is variable. ${ }^{76}$ Alternative treatments include foscarnet and gancyclovir in acyclovir resistant cases.

Syphilis occurring concomitantly in patients with HIV infection has an aggressive course with increased incidence and faster progression to neurosyphilis; increased clinical severity and ineffective treatment. Neurosyphilis frequently presents with ocular disease in patients with AIDS and a CSF examination should be performed in all patients with HIV presenting with syphilitic eye disease. ${ }^{77}$ Clinically, optic neuritis may present with papillitis, ${ }^{78-83}$ retrobulbar optic neuritis, ${ }^{84-86}$ neuroretinitis ${ }^{87}$ and optic perineuritis. ${ }^{88,89}$ Optic nerve syphiloma (gummata) seen on ultrasonography has also been reported in a HIV positive patient..$^{90}$ Visual outcomes of optic neuritis with treatment remain variable.

Cryptococcus neoformans infection is another common cause of neurologic and neuro-ophthalmologic disease in AIDS. ${ }^{91}$ Optic nerve inflammation can produce papillitis $^{9}$, retrobulbar optic neuritis ${ }^{92-94}$ and optic perineuritis. ${ }^{95}$ Chiasmal involvement with visual field loss has also been reported. ${ }^{96}$ Visual loss in cryptococcal meningitis results either from direct fungal infiltration of the anterior visual pathway and the perioptic meninges with resultant necrosis of optic nerve fibers, ${ }^{94,97}$ or from adhesive or constrictive arachnoiditis leading to vascular compromise or optic nerve compression..$^{95}$ Prompt medical intervention with intravenous amphotericin $\mathrm{b}$ and 5-flucytosine before permanent nerve damage develops may preserve vision.

Optic neuritis has also been reported with mycobacterium tuberculosis, ${ }^{9}$ histoplasmosis, ${ }^{98,99}$ hepatitis $\mathrm{B}^{100}$ and Bartonella henselae (neuroretinitis and aseptic meningitis). ${ }^{101}$ Sudden blindness from chiasmal infarction caused by progressive rhino-orbital cerebral mucormycosis that produced occlusive vasculitis was reported in a patient with both diabetes and AIDS. ${ }^{102}$

\section{Papilledema}

The incidence of papilledema in AIDS is highly variable with a range of $1.5 \%-27 \% .{ }^{9,39,103}$ Papilledema may develop from raised intracranial pressure from CNS infections or neoplastic processes. Papilledema in AIDS patients has been reported in cryptococcal meningitis, ${ }^{104-109}$ cerebral toxoplasmosis, herpes zoster, neurosyphilis, ${ }^{110}$ cytomegalovirus, ${ }^{111}$ lymphoma, ${ }^{112}$ tuberculous meningitis and tuberculoma. 
Rarely, papilledema from direct CNS involvement by HIV has also been described..$^{9,113}$ Optic nerve sheath fenestration procedure has been used to preserve vision in cases of papilledema resulting from cryptococcal meningitis. ${ }^{114,115}$

\section{Other causes of optic neuropathy}

Lymphomatous infiltration of the optic nerve has been reported in patients with HIV/AIDS. ${ }^{113}$ Dense lymphomatous infiltration of optic nerves with necrotizing vasculitis of the peripapillary retinal vessels was found in a patient with AIDS who suffered bilateral sequential central retinal vein occlusion. ${ }^{16}$ Lymphomatous infiltration of the anterior visual pathways was reported in patients with AIDS by other authors. ${ }^{117,118}$

Brack et al describe a patient with anterior ischemic optic neuropathy confirmed on fluorescein angiogram as the presenting symptom of AIDS. ${ }^{119}$

A case of bilateral sequential optic neuropathy attributable to LHON (genetic analysis was positive for 14484 mutation) was seen in an AIDS patient on antiretroviral therapy. It was proposed that LHON was precipitated by mitochondrial toxicity induced by the antiretroviral therapy. ${ }^{120}$

While optic atrophy may develop following any form of optic neuropathy in HIV/AIDS, atrophy may develop in the absence of known prior history of optic nerve disease. ${ }^{9,22}$

\section{Other abnormalities of the afferent pathways}

Visual field defects in AIDS are produced by lesions involving the afferent pathways. The anterior visual pathway lesions as described above usually produce nerve fiber bundle defects. Lesions of the retrochiasmal pathways produce homonymous hemianopia and have resulted from toxoplasmosis, cryptococcosis, cerebral astrocytoma, ${ }^{121}$ neurosyphilis, ${ }^{122}$ tuberculosis, progressive multifocal leukoencephalopathy, ${ }^{123-129}$ and lymphoma. Visual field defects have been reported in patients with normal visual acuity ${ }^{130,131}$ and without infectious retinopathy ${ }^{131,132}$ and are believed to result from damage to the inner retina. Cortical blindness and visuo-spatial abnormalities could result from involvement of the primary or association visual cortices.

Abnormal contrast sensitivity and abnormal color vision ${ }^{133-137}$ has been reported in patients with HIV infection despite good immune status and visual acuity. While severe impairments producing tritan defect reflects neuroretinal dysfunction, presence of deutan and proton defects indicate probable optic nerve involvement. ${ }^{135,136}$
Abnormalities on the visual evoked potential (VEP) may be seen in 3\%-49\% patients with HIV, despite normal visual acuity indicating subclinical dysfunction of the afferent pathways. ${ }^{9}{ }^{138-142}$ While VEP latency may be normal in asymptomatic seropositive subjects, prolonged latency can be seen in neurologically symptomatic subjects with AIDS ${ }^{143}$ suggesting that neurologically symptomatic patients may have more damage to the visual pathway.

\section{HIV neuro-retinal disorder}

Monochromatic photography has demonstrated nerve fiber layer infarcts in HIV patients with and without retinopathy ${ }^{144}$ believed to reflect primary lesions of the retinal ganglion cells or nerve fibers. Optical coherence tomography (OCT) and frequency doubling perimetry have shown that visual dysfunction can occur in eyes of HIV patients without infectious retinopathy from damage to the inner retina (HIVneuroretinal disorder). ${ }^{145}$ Studies using the third-generation OCT have demonstrated significant retinal nerve fiber layer (RNFL) thinning in HIV patients with low CD4 counts and without infectious retinitis compared with a subgroup of patients with CD4 count above 100 and HIV-negative control subjects. ${ }^{146,147}$ This may prove useful in detecting early subclinical HIV associated visual loss. The loss of the nerve fiber layer leads to sub-clinical deficits. Abnormalities of color vision and contrast sensitivity have been shown to correlate with thinning of peripapillary RNFL particularly the temporal quadrant. Preferential damage to small- caliber axons in the maculopapillary bundle possibly associated with mitochondrial dysfunction has been hypothesized. This provides a potential disease mechanism for HIV-associated "neuroretinal disorder." 148

\section{Abnormalities of ocular motility}

Ocular dysmotility in HIV/AIDS can result from nuclear, supranuclear, or infranuclear lesions resulting in cranial nerve palsy, gaze palsies, internuclear ophthalmoplegia and nystagmus ${ }^{40}$ often in association with other neurological deficits such as hemiplegia, hemianesthesia, ataxia, and tremors. Rarely, they form the presenting features of HIV/AIDS. ${ }^{149}$

\section{Supranuclear defects}

Disorders of conjugate gaze dynamics are common in AIDS. Saccadic and smooth pursuit dysfunction has been noted in patients with AIDS and can be an early sign of CNS HIV infection. ${ }^{150-152}$ Most patients are unaware of their ocular motility defects. Imaging may not reveal any structural abnormality. Using simple bedside techniques for testing saccades, 
prolonged saccadic latency, or slowed saccadic movement has been reported in AIDS and may indicate disease involving basal ganglia. ${ }^{151}$ Infrared oculography has demonstrated abnormal saccades and smooth pursuit in patients with HIV and AIDS. ${ }^{153,154}$ Saccadic problems in HIV positive patients include hypometric saccades, anticipatory saccades, wrong way saccades, abnormal antisaccades, fixation instability with saccadic intrusions and square wave jerks, slowed saccadic duration both for abducting and adducting saccades, and reduced saccadic velocity. ${ }^{153-156}$ Smooth pursuit dysfunction includes saccadic pursuit and decreased smooth pursuit gain.

Abnormal saccades and smooth pursuit may be an early indicator of AIDS dementia complex (ADC) $)^{153,155,157}$ characterized by progressive cognitive loss with behavioral problems and slowing of rapid motor movements. These ocular motility problems may be encountered even in patients without signs of ADC. ${ }^{152}$ Early detection may lead to prompt treatment with a better prognosis. Severity of the ocular motility dysfunction has been correlated with the severity of AIDS dementia.

The neuroanatomic substrate causing slowed saccades in HIV infection is unknown. However it has been postulated that the defect may lie in the burst neurons of the parapontine reticular formation rather than a defect in the neural input from the frontal eye field. Also it has been proposed that involvement of basal ganglia in ADC may give abnormal voluntary saccades and diffuse cortical atrophy in ADC may affect the generation of smooth pursuit movement.

Other supranuclear abnormalities of eye movements include convergence insufficiency, ${ }^{150}$ reverse ocular dipping (slow upward deviation of the eyes followed by a rapid return to midposition), ${ }^{158}$ and nystagmus (from brainstem and cerebellar lesions). ${ }^{159}$

Opsoclonus-myoclonus-ataxia (OMA) syndrome is a rare neurological disorder characterized by multidirectional chaotic saccadic eye movements, accompanied by myoclonus and rarely cerebellar ataxia. HIV-associated OMA has been described as a consequence of a deranged immune system when the $\mathrm{CD} 4 / \mathrm{CD} 8$ ratio is reduced, ${ }^{160}$ at the time of probable seroconversion in HIV $^{161,162}$ and immune reconstitution ${ }^{162,163}$ following initiation of anti-retroviral therapy. Spontaneous recovery may occur. ${ }^{162}$ Improvement with use of lorazepam, ${ }^{161}$ immunoglobulins ${ }^{164}$ and prednisone has been noted.

\section{Cranial nerve palsies}

Toxoplasma has a predilection for involving the brainstem and thalamus and can produce nuclear third, ${ }^{165,166}$ fourth, and sixth cranial nerve palsies. Other opportunistic infections such as CMV, herpes simplex and herpes zoster can cause brainstem encephalitis resulting in brainstem neuro-ophthalmic signs such as internuclear ophthalmoplegia, ${ }^{167-69}$ vertical gaze palsy, ${ }^{170,171}$ horizontal gaze palsy, ${ }^{172,173}$ bilateral fourth nerve palsy, ${ }^{174}$ sixth nerve palsy, ${ }^{175}$ seventh nerve palsy, ${ }^{169,170,173}$ and nystagmus. Dorsal midbrain syndrome characterized by impaired upgaze, lid retraction (Collier's sign), convergence retraction nystagmus, light near dissociation and ataxia has also been described in AIDS. ${ }^{176-180}$

Isolated and multiple cranial neuropathies have been reported in HIV/AIDS. These result from brainstem encephalitides, neoplastic meningitides (lymphoma), mass lesions and vasculitis. Nine percent of HIV related neurological disease is heralded by cranial neuropathy. ${ }^{180}$ In a study of 589 patients with neurological manifestations, 3\% had ocular cranial nerve palsy ${ }^{181}$ with third and sixth nerve palsies being the most common. Toxoplasmosis and cryptococcosis have been reported as the two most common causes. Multiple cranial neuropathies can occur at the time of HIV seroconversion, ${ }^{182}$ and have been reported with cryptococcal meningitis, ${ }^{183}$ toxoplasmosis, CNS lymphoma, ${ }^{184,185}$ and multifocal CMV encephalitis. ${ }^{186}$

Unilateral or bilateral third nerve palsy in AIDS has been reported secondary to toxoplasmosis, ${ }^{187}$ cryptococcosis, ${ }^{9}$ tuberculosis, herpes zoster, CMV polyradiculopathy (involving the oculomotor nerve exit zone), ${ }^{175}$ leptomeningeal lymphoma, ${ }^{184,188}$ and Burkitt's lymphoma. ${ }^{189}$ Episodic third nerve palsy has been reported in cryptococcal meningitis occurring in AIDS and was attributed to elevated intracranial pressure. ${ }^{190}$

Trochlear nerve palsy is rare in AIDS and has been reported with CNS toxoplasmosis, varicella zoster cryptococcal meningitis, primary HIV infection, and lymphoma. Ischemic trochlear nerve palsy was described in an HIV infected individual on anti-retroviral therapy. ${ }^{191}$ Bilateral trochlear nerve palsy has been reported in HSV1 brainstem encephalitis ${ }^{174}$ and in cryptococcal meningitis ${ }^{192}$ from post inflammatory shrinking of the arachnoid that stretched the fourth nerve at its emergence from the dorsal midbrain. Bilateral trochlear nerve palsy was also seen in primary CNS lymphoma invading the dorsal mesencephalon and producing hydrocephalus. ${ }^{193}$

The abducens nerve is the most commonly affected cranial nerve in HIV/AIDS. It has been reported in toxoplasmosis, ${ }^{194}$ cryptococcal meningitis, ${ }^{195}$ tuberculosis, histoplasmosis, herpes encephalitis, primary HIV infection, and meningeal lymphomatosis. ${ }^{184}$ Neurosyphilis can rarely affect the abducens nerve. ${ }^{196}$ Abducens nerve palsy in AIDS has also 
Table I Summary of the neuro-ophthalmic manifestations of afferent visual pathway disease in patients with HIVIAIDS

\begin{tabular}{|c|c|c|}
\hline & Manifestations & Treatment \\
\hline Primary HIV optic neuropathy & Papillitis, retrobulbar optic neuritis, neuroretinitis & HAART \\
\hline \multicolumn{3}{|l|}{ Infectious optic neuropathy } \\
\hline CMV & $\begin{array}{l}\text { papillitis with peripapillary retinitis, } \\
\text { retro-bulbar neuritis }\end{array}$ & $\begin{array}{l}\text { Intravenous foscarnet/gancyclovir } \\
\text { or oral valacyclovir }\end{array}$ \\
\hline Toxoplasmosis & $\begin{array}{l}\text { Papillitis, retro-bulbar optic neuritis and } \\
\text { neuroretinitis often with retinochoroiditis }\end{array}$ & $\begin{array}{l}\text { Systemic therapy - sulphadiazine, } \\
\text { pyrimethamine, clindamycin, } \\
\text { trimethoprim-sulphamethaxozole, } \\
\text { minocycline; } \\
\text { Intravitreal clindamycin }\end{array}$ \\
\hline Herpes zoster & $\begin{array}{l}\text { Optic neuritis (papillitis, retrobulbar optic neuritis } \\
\text { and neuroretinitis); herpes zoster ophthalmicus } \\
\text { (HZO); acute retinal necrosis (ARN), progressive } \\
\text { outer retinal necrosis (PORN) }\end{array}$ & $\begin{array}{l}\text { Intravenous acyclovir, alternatively } \\
\text { IV foscarnet and gancyclovir }\end{array}$ \\
\hline Herpes simplex & $\begin{array}{l}\text { Papillitis and optic atrophy in association } \\
\text { with ARN, PORN }\end{array}$ & $\begin{array}{l}\text { Intravenous acyclovir, alternatively } \\
\text { IV foscarnet and gancyclovir }\end{array}$ \\
\hline Syphilis & $\begin{array}{l}\text { Papillitis, retrobulbar optic neuritis, } \\
\text { neuroretinitis, optic perineuritis, } \\
\text { optic nerve syphiloma }\end{array}$ & $\begin{array}{l}\text { Procaine penicillin } G \text { and } \\
\text { probenacid }\end{array}$ \\
\hline Cryptococcus neoformans & $\begin{array}{l}\text { Papillitis, retrobulbar optic neuritis, } \\
\text { optic perineuritis and chiasmitis }\end{array}$ & $\begin{array}{l}\text { Intravenous amphotericin b and } \\
5 \text {-flucytosine, oral fluconazole, } \\
\text { oral itraconazole }\end{array}$ \\
\hline $\begin{array}{l}\text { Others: Mycobacterium tuberculosis, Hepatitis B, } \\
\text { Histoplasmosis, Bartonella }\end{array}$ & $\begin{array}{l}\text { Papillitis, retrobulbar neuritis, } \\
\text { neuroretinitis }\end{array}$ & Treat underlying cause \\
\hline Other optic neuropathy & Loss of vision with optic nerve & No specific treatment except \\
\hline Anterior ischemic optic neuropathy & swelling or pallor & treatment of underlying cause \\
\hline Infiltrative optic neuropathy & & such as lymphoma if found \\
\hline \multicolumn{3}{|l|}{ Optic atrophy } \\
\hline Retrochiasmal pathway lesions (meningitis, encephalitis) & Papilledema & Treat underlying disorder \\
\hline Toxoplasmosis, CMV, Cryptococcosis, Neurosyphilis, & Visual field defects (homonymous) & \\
\hline $\begin{array}{l}\text { Tuberculosis, Progressive multifocal leukoencephalopathy, } \\
\text { Lymphoma }\end{array}$ & Cortical blindness & \\
\hline HIV-Neuro-retinal disorder & $\begin{array}{l}\text { Retinal nerve fiber layer defects } \\
\text { Retinal nerve fiber thinning }\end{array}$ & HAART \\
\hline Other disturbances of visual function & $\begin{array}{l}\text { Abnormal contrast sensitivity } \\
\text { Abnormal color vision } \\
\text { Abnormal VEP }\end{array}$ & No specific therapy; HAART \\
\hline
\end{tabular}

Abbreviations: ARN, Acute retinal necrosis; CMV, Cytomegalovirus; HIVIAIDS, Human Immunodeficiency Virus/acquired immune deficiency syndrome; HZO, Herpes Zoster Ophthalmicus; PORN, Progressive outer retinal necrosis; VEP, Visual Evoked Potential.

been reported with petrous apex involvement (Gradenigo's syndrome $)^{197,198}$ and with lymphomatous involvement of the cavernous sinus. ${ }^{199}$

Peripheral seventh nerve palsy can occur at any stage of HIV infection ${ }^{9,200}$ including the very early stages before seroconversion. Unilateral and bilateral peripheral facial palsies have been reported to be the presenting features of HIV. ${ }^{201} \mathrm{Neu}-$ rologic prognosis for recovery in these cases is good. Etiologic cause of the peripheral seventh nerve palsy in AIDS patients include HIV encephalopathy, ${ }^{202}$ Herpes zoster infection, ${ }^{200,203}$ cryptococcal meningitis, neurosyphilis, ${ }^{204}$ and meningeal lymphomatosis. ${ }^{184,205}$ Not infrequently, neurosyphilis can produce palsies of the seventh and eighth cranial nerves. ${ }^{196,206}$

Multiple cranial neuropathies can also result from involvement of the cavernous sinus and orbital apex from lymphomatous infiltration and secondary infections in HIV/AIDS. Bilateral enlargement of cavernous sinuses from lymphomatous infiltration was described in an HIV positive patient who presented with bilateral fifth and sixth nerve palsies. ${ }^{207}$ Complete ophthalmoplegia with ptosis was reported in an HIV positive patient from Burkitt's lymphoma infiltrating the cavernous sinus. ${ }^{208}$ A $3 \frac{1}{2} 2$ - year old boy with complete ophthalmoplegia in one eye and sixth nerve palsy in the other was found to have non-Hodgkin's lymphoma in the nasopharynx extending into the ethmoid sinus and medial orbits. ${ }^{199}$ Other causes of cranial neuropathy from involvement of the cavernous sinus and orbital apex include herpes zoster ophthalmicus, ${ }^{209}$ eosinophilic granuloma of the cavernous sinus, superior orbital fissure and orbital apex, ${ }^{210}$ and sino-orbital aspergillosis. ${ }^{211}$ 
Table 2 Summary of the neuro-ophthalmic manifestations of efferent visual pathway disease in patients with HIV/AIDS

\begin{tabular}{|c|c|c|}
\hline & Manifestations & Treatment \\
\hline \multirow[t]{6}{*}{ Supranuclear defects } & Saccadic abnormalities & HAART \\
\hline & Smooth pursuit abnormalities & \\
\hline & Convergence insufficiency & Convergence exercise \\
\hline & Opsoclonus myoclonus ataxia syndrome & $\begin{array}{l}\text { Lorazepam, immunoglobulins, } \\
\text { prednisone }\end{array}$ \\
\hline & Dorsal midbrain syndrome, Internuclear ophthalmoplegia, Gaze & Treat underlying cause \\
\hline & palsy-Horizontal and vertical, Cranial neuropathy, Nystagmus & \\
\hline \multicolumn{3}{|c|}{ Nuclear and infranuclear defects } \\
\hline \multirow[t]{2}{*}{ Oculomotor nerve palsy } & Toxoplasmosis, cryptococcosis, tuberculosis, herpes zoster, CMV, & Treat underlying cause \\
\hline & polyradiculopathy, Leptomeningeal lymphoma, Burkitt's lymphoma & Strabismus surgery if needed \\
\hline \multirow[t]{2}{*}{ Trochlear nerve palsy } & Toxoplasmosis, varicella zoster, Cryptococcal meningitis, Primary & Treat underlying cause \\
\hline & HIV infection, HSV I brainstem encephalitis, lymphoma, ischemia & Strabismus surgery if needed \\
\hline \multirow[t]{2}{*}{ Abducens nerve palsy } & Toxoplasmosis, cryptococcal meningitis, Tuberculosis, Histoplasmosis, Herpes & Treat underlying cause \\
\hline & encephalitis, Neurosyphilis, Primary HIV infection, Meningeal lymphomatosis & Strabismus surgery if needed \\
\hline \multirow[t]{2}{*}{ Facial nerve palsy } & HIV, herpes zoster infection, Cryptococcal meningitis, Neurosyphilis, & Treat underlying cause \\
\hline & Meningeal lymphomatosis & Protect corneal exposure \\
\hline \multirow[t]{6}{*}{ Multiple cranial neuropathies } & Brainstem encephalitides & Treat underlying cause \\
\hline & Cryptococcal meningitis & \\
\hline & Toxoplasmosis & \\
\hline & Multifocal CMV encephalitis & \\
\hline & Neoplastic meningitides & \\
\hline & Cavernous sinus and orbital apex lesions & \\
\hline \multirow[t]{2}{*}{ Muscle disease } & CPEO like syndromes from HAART & Ptosis - surgical repair \\
\hline & & $\begin{array}{l}\text { Withdraw offending agents or } \\
\text { use alternate HAART drugs }\end{array}$ \\
\hline \multirow[t]{4}{*}{ Pupillary abnormalities } & Abnormal pupil cycle time & No specific treatment \\
\hline & Holmes Adie's pupil & \\
\hline & Horner's syndrome & \\
\hline & Light near dissociation (syphilis) & \\
\hline
\end{tabular}

Abbreviations: CMV, Cytomegalovirus; CPEO, chronic progressive external ophthalmoplegia; HAART, highly active antiretroviral therapy; HIV, Human Immunodeficiency Virus; HSV, Herpes simplex virus.

\section{Chronic progressive external ophthalmoplegia (CPEO)}

CPEO- like syndromes consisting of ptosis and ophthalmoplegia occasionally occur in patients with long-standing HIV infection especially with long-term treatment with HAART. $^{212-214}$ It has been postulated that these syndromes may develop from accumulated mitochondrial toxicity induced by the anti-retroviral drugs and superimposed upon a preexisting subclinical genetic mitochondrial disorder. ${ }^{213}$ Lipodystrophy is an adverse effect of HAART that usually precedes the development of ophthalmoplegia in these cases. Improvement has been documented by withdrawing the offending agents or by using alternative regimens.

\section{Pupillary abnormalities}

Pupillary abnormalities seen in HIV/AIDS include light-near dissociation secondary to syphilis and other opportunistic infections,${ }^{40}$ bilateral Holmes-Adies pupil (believed to be secondary to loss of ganglion cells in the parasympathetic ciliary ganglia from autonomic HIV neuropathy $)^{215}$ and Horner's syndrome. ${ }^{40,216}$ Abnormalities of the pupil-cycle time in HIV infected subjects and controls demonstrated dysfunction in the pupil reflex $\operatorname{arc}^{217}$ which indicates subclinical ocular autonomic dysfunction starting in the early stages of HIV infection.

\section{Screening}

There are no specific screening guidelines for neuro-ophthalmic manifestations in HIV-AIDS, although protocols for other ocular manifestations such as CMV retinitis exist. Ocular screening (particularly aimed at CMV retinitis) at onset of AIDS and 3-6 monthly thereafter has been proposed. ${ }^{218-220}$

With reports of subclinical visual dysfunction such as retinal nerve fiber layer loss in HIV neuro-retinal disorder, we recommend a comprehensive ocular examination at baseline and annually thereafter for patients without AIDS. All patients with AIDS, especially neurological AIDS should be screened at 3-6 monthly intervals. Screening should include assessment of visual function (acuity, color, contrast and fields), ocular motility, anterior and posterior segment examination, and examination of ocular adnexa, pupils and retinal nerve fiber layer thickness. 


\section{Conclusion}

Neuro-ophthalmic manifestations of AIDS are protean and complex and could involve any part of the afferent and efferent system. The bulk of the problems arise from opportunistic infections and malignancies. However, HIV itself may be the underlying cause in some cases. Adequate ocular screening protocols for neuro-ophthalmologic manifestations currently do not exist. The authors propose a comprehensive ocular screening examination at baseline and periodically thereafter.

\section{Disclosure}

The authors report no conflict of interest in this work.

\section{References}

1. Gottlieb MS, Schroff R, Schanker HM, et al. Pneumocystis carinii pneumonia and mucosal candidiasis in previously healthy homosexual men: evidence of a new acquired cellular immunodeficiency. $N$ Engl J Med. 1981;305(24):1425-1431.

2. Gallo RC, Sarin PS, Gelmann EP, et al. Isolation of human T-cell leukemia virus in acquired immune deficiency syndrome (AIDS). Science. 1983;220(4599):865-867.

3. Levy RM, Bredesen DE, Rosenblum ML. Neurological manifestations of the acquired immunodeficiency syndrome (AIDS): experience at UCSF and review of the literature. J Neurosurg. 1985;62(4): 475-495.

4. Simpson DM, Berger JR. Neurologic manifestations of HIV infection. Med Clin North Am. 1996;80(6):1363-1394.

5. Skiest DJ. Focal neurological disease in patients with acquired immunodeficiency syndrome. Clin Infect Dis. 2002;34(1): 103-115.

6. Gray F, Chretien F, Vallat-Decouvelaere AV, Scaravilli F. The changing pattern of HIV neuropathology in the HAART era. J Neuropathol Exp Neurol. 2003;62(5):429-440.

7. Oliveira JF, Greco DB, Oliveira GC, Christo PP, Guimaraes MD, Oliveira RC. Neurological disease in HIV-infected patients in the era of highly active antiretroviral treatment: a Brazilian experience. Rev Soc Bras Med Trop. 2006;39(2):146-151.

8. Holland GN, Gottlieb MS, Yee RD, Schanker HM, Pettit TH. Ocular disorders associated with a new severe acquired cellular immunodeficiency syndrome. Am J Ophthalmol. 1982;93(4): 393-402.

9. Mwanza JC, Nyamabo LK, Tylleskar T, Plant GT. Neuro-ophthalmological disorders in HIV infected subjects with neurological manifestations. Br J Ophthalmol. 2004;88(11):1455-1459.

10. Hodge WG, Seiff SR, Margolis TP. Ocular opportunistic infection incidences among patients who are HIV positive compared to patients who are HIV negative. Ophthalmology. 1998;105(5): 895-900.

11. Biswas J, Madhavan HN, Kumarasamy N, Solomon S. Blepharitis and lid ulcer as initial ocular manifestation in acquired immunodeficiency syndrome patients. Indian J Ophthalmol. 1997;45(4):233-234.

12. Biswas J, Therese L, Kumarasamy N, Solomon S, Yesudian P. Lid abscess with extensive molluscum contagiosum in a patient with acquired immunodeficiency syndrome. Indian J Ophthalmol. 1997; 45(4):234-236.

13. Charles NC, Friedberg DN. Epibulbar molluscum contagiosum in acquired immune deficiency syndrome. Case report and review of the literature. Ophthalmology. 1992;99(7):1123-1126.

14. Curtis TH, Durairaj VD. Conjunctival Kaposi sarcoma as the initial presentation of human immunodeficiency virus infection. Ophthal Plast Reconstr Surg. 2005;21(4):314-315.

15. Holland GN, Pepose JS, Pettit TH, Gottlieb MS, Yee RD, Foos RY. Acquired immune deficiency syndrome. Ocular manifestations. Ophthalmology. 1983;90(8):859-873.
16. Osahon AI, Onunu AN. Ocular disorders in patients infected with the human immunodeficiency virus at the University of Benin Teaching Hospital, Benin City, Nigeria. Niger J Clin Pract. 2007;10(4): 283-286.

17. Teich SA. Conjunctival vascular changes in AIDS and AIDS-related complex. Am J Ophthalmol. 1987;103(3 Pt 1):332-333.

18. Gharai S, Venkatesh P, Garg S, Sharma SK, Vohra R. Ophthalmic manifestations of HIV infections in India in the era of HAART: analysis of 100 consecutive patients evaluated at a tertiary eye care center in India. Ophthalmic Epidemiol. 2008;15(4): 264-271.

19. Lim SA, Heng WJ, Lim TH, Leo YS, Wong SY. Ophthalmic manifestations in human immunodeficiency virus infection in Singapore. Ann Acad Med Singapore. 26(5):575-580.

20. Biswas J, Madhavan HN, George AE, Kumarasamy N, Solomon S. Ocular lesions associated with HIV infection in India: a series of 100 consecutive patients evaluated at a referral center. Am J Ophthalmol. 2000;129(1):9-15.

21. Biswas J, Sudharshan S. Anterior segment manifestations of human immunodeficiency virus/acquired immune deficiency syndrome. Indian J Ophthalmol. 2008;56(5):363-375.

22. Biswas PN, Saha B, Ghosh S, et al. Ophthalmic manifestations in people living with HIV attending a tertiary care centre of Eastern India. J Indian Med Assoc. 2008;106(5):292-294.

23. Shah SU, Kerkar SP, Pazare AR. Evaluation of ocular manifestations and blindness in HIV/AIDS patients on HAART in a tertiary care hospital in western India. Br J Ophthalmol. 2009;93(1):88-90.

24. Jabs DA, Green WR, Fox R, Polk BF, Bartlett JG. Ocular manifestations of acquired immune deficiency syndrome. Ophthalmology. 1989; 96(7):1092-1099.

25. Rao NA, Zimmerman PL, Boyer D, et al. A clinical, histopathologic, and electron microscopic study of Pneumocystis carinii choroiditis. Am J Ophthalmol. 1989;107(3):218-228.

26. Jones MR, Cunningham ET Jr. Bartonella henselae-associated acute multifocal retinitis in a patient with acquired immunodeficiency syndrome. Retina. 1997;17(5):457-459.

27. Biswas J, Raizada S, Gopal L, Kumarasamy N, Solomon S. Bilateral frosted branch angiitis and cytomegalovirus retinitis in acquired immunodeficiency syndrome. Indian J Ophthalmol. 1999;47(3): 195-197.

28. Schanzer MC, Font RL, O'Malley RE. Primary ocular malignant lymphoma associated with the acquired immune deficiency syndrome. Ophthalmology. 1991;98(1):88-91.

29. Holland GN. AIDS and ophthalmology: the first quarter century. Am J Ophthalmol. 2008;145(3):397-408.

30. Lai TY, Wong RL, Luk FO, Chow VW, Chan CK, Lam DS. Ophthalmic manifestations and risk factors for mortality of HIV patients in the posthighly active anti-retroviral therapy era. Clin Experiment Ophthalmol. 2011;39(2):99-104.

31. Jabs DA, Van Natta ML, Thorne JE, et al. Course of cytomegalovirus retinitis in the era of highly active antiretroviral therapy: 2. Second eye involvement and retinal detachment. Ophthalmology. 2004; 111(12):2232-2239.

32. Jabs DA, Van Natta ML, Thorne JE, et al. Course of cytomegalovirus retinitis in the era of highly active antiretroviral therapy: 1. Retinitis progression. Ophthalmology. 2004;111(12):2224-2231.

33. Erdol H, Turk A, Caylan R. An unusual cause of central retinal artery occlusion: acquired immunodeficiency syndrome. Eur J Ophthalmol. 2007;17(4):671-673.

34. Dunn JP, Yamashita A, Kempen JH, Jabs DA. Retinal vascular occlusion in patients infected with human immunodeficiency virus. Retina. 2005;25(6):759-766.

35. Wen F, Chen X, Li H, Liao R, Wu D. Bilateral central retinal vein occlusions combined with artery occlusions in a patient with acquired immune deficiency syndrome. Yan Ke Xue Bao. 2002;18(1): 27-29.

36. Bachman DM, Green WR, Holman R. Bilateral ophthalmic artery occlusion in a patient with acquired immunodeficiency syndrome and central nervous system lymphoma. Ophthalmology. 2002;109(6): 1142-1147. 
37. Freeman WR, Lerner CW, Mines JA, et al. A prospective study of the ophthalmologic findings in the acquired immune deficiency syndrome. Am J Ophthalmol. 1984;97(2):133-142.

38. Palestine AG, Rodrigues MM, Macher AM, et al. Ophthalmic involvement in acquired immunodeficiency syndrome. Ophthalmology. 1984;91(9):1092-1099.

39. Mansour AM. Neuro-ophthalmic findings in acquired immunodeficiency syndrome. J Clin Neuroophthalmol. 1990;10(3):167-174.

40. Keane JR. Neuro-ophthalmologic signs of AIDS: 50 patients. Neurology. 1991;41(6):841-845.

41. Sweeney BJ, Manji H, Gilson RJ, Harrison MJ. Optic neuritis and HIV-1 infection. J Neurol Neurosurg Psychiatry. 1993;56(6): 705-707.

42. Woods AD, Caputo MK. Neuro-ophthalmic manifestations of AIDS. Optom Clin. 1996;5(3-4):113-152.

43. Newman NJ, Lessell S. Bilateral optic neuropathies with remission in two HIV-positive men. J Clin Neuroophthalmol. 1992;12(1):1-5.

44. Goldsmith P, Jones RE, Ozuzu GE, Richardson J, Ong EL. Optic neuropathy as the presenting feature of HIV infection: recovery of vision with highly active antiretroviral therapy. $\mathrm{Br} J$ Ophthalmol. 2000;84(5):551-553.

45. Larsen M, Toft PB, Bernhard P, Herning M. Bilateral optic neuritis in acute human immunodeficiency virus infection. Acta Ophthalmol Scand. 1998;76(6):737-738.

46. Jimenez Caballero PE, Servia Candela M. Bilateral optic neuropathy in an HIV patient. Neurologia. May 2010;25(4):267-268.

47. Berger JR, Sheremata WA, Resnick L, Atherton S, Fletcher MA, Norenberg M. Multiple sclerosis-like illness occurring with human immunodeficiency virus infection. Neurology. 1989;39(3): 324-329.

48. Tenhula WN, Xu SZ, Madigan MC, Heller K, Freeman WR, Sadun AA. Morphometric comparisons of optic nerve axon loss in acquired immunodeficiency syndrome. Am J Ophthalmol. 1992; 113(1):14-20.

49. Sadun AA, Pepose JS, Madigan MC, Laycock KA, Tenhula WN, Freeman WR. AIDS-related optic neuropathy: a histological, virologica and ultrastructural study. Graefes Arch Clin Exp Ophthalmol. 1995 233(7):387-398.

50. Madigan MC, Sadun AA, Rao NS, Dugel PU, Tenhula WN, Gill PS. Tumor necrosis factor-alpha (TNF-alpha)-induced optic neuropathy in rabbits. Neurol Res. 1996;18(2):176-184.

51. Lin XH, Kashima Y, Khan M, Heller KB, Gu XZ, Sadun AA. An immunohistochemical study of TNF-alpha in optic nerves from AIDS patients. Curr Eye Res. 1997;16(10):1064-1068.

52. Saadati HG, Khan IA, Lin XH, Kadakia AB, Heller KB, Sadun AA. Immunolocalization of IL-1beta and IL-6 in optic nerves of patients with AIDS. Curr Eye Res. 1999;19(3):264-268.

53. Babu K, Murthy KR, Rajagopalan N, Satish B. Vision recovery in human immunodeficiency virus-infected patients with optic neuropathy treated with highly active antiretroviral therapy: a case series. Indian J Ophthalmol. 2009;57(4):315-318.

54. Burton BJ, Leff AP, Plant GT. Steroid-responsive HIV optic neuropathy. J Neuroophthalmol. 1998;18(1):25-29.

55. Petrovich MS, Hsu HY, Gu X, Dugal P, Heller KB, Sadun AA. Pentoxifylline suppression of TNF-alpha mediated axonal degeneration in the rabbit optic nerve. Neurol Res. 1997;19(5):551-554.

56. Winward KE, Hamed LM, Glaser JS. The spectrum of optic nerve disease in human immunodeficiency virus infection. Am JOphthalmol. 1989;107(4):373-380.

57. Friedman AH. The retinal lesions of the acquired immune deficiency syndrome. Trans Am Ophthalmol Soc. 1984;82:447-491.

58. Martenet AC. Unusual ocular lesions in AIDS. Int Ophthalmol. 1990;14(5-6):359-363.

59. Robinson MR, Streeten BW, Hampton GR, Siebold EC, Taylor-Findlay C. Treatment of cytomegalovirus optic neuritis with dihydroxy propoxymethyl guanine. Am J Ophthalmol. 1986;102(4):533-534.

60. Gross JG, Sadun AA, Wiley CA, Freeman WR. Severe visual loss related to isolated peripapillary retinal and optic nerve head cytomegalovirus infection. Am J Ophthalmol. 1989;108(6):691-698.
61. Park KH, Bang JH, Park WB, et al. Retrobulbar optic neuritis and meningoencephalitis following progressive outer retinal necrosis due to CMV in a patient with AIDS. Infection. 2008;36(5):475-479.

62. Grossniklaus HE, Frank KE, Tomsak RL. Cytomegalovirus retinitis and optic neuritis in acquired immune deficiency syndrome. Report of a case. Ophthalmology. 1987;94(12):1601-1604.

63. Patel SS, Rutzen AR, Marx JL, Thach AB, Chong LP, Rao NA. Cytomegalovirus papillitis in patients with acquired immune deficiency syndrome. Visual prognosis of patients treated with ganciclovir and/or foscarnet. Ophthalmology. 1996;103(9):1476-1482.

64. Ioannidis AS, Bacon J, Frith P. Juxtapapillary cytomegalovirus retinitis with optic neuritis. J Neuroophthalmol. 2008;28(2):128-130.

65. Holland GN, Engstrom RE Jr, Glasgow BJ, et al. Ocular toxoplasmosis in patients with the acquired immunodeficiency syndrome. $A m J$ Ophthalmol. 1988;106(6):653-667.

66. Grossniklaus HE, Specht CS, Allaire G, Leavitt JA. Toxoplasma gondii retinochoroiditis and optic neuritis in acquired immune deficiency syndrome. Report of a case. Ophthalmology. 1990; 97(10): 1342-1346.

67. Engstrom RE Jr, Holland GN, Margolis TP, et al. The progressive outer retinal necrosis syndrome. A variant of necrotizing herpetic retinopathy in patients with AIDS. Ophthalmology. 1994;101(9):1488-1502.

68. Friedlander SM, Rahhal FM, Ericson L, et al. Optic neuropathy preceding acute retinal necrosis in acquired immunodeficiency syndrome. Arch Ophthalmol. 1996;114(12):1481-1485.

69. Meenken C, van den Horn GJ, de Smet MD, van der Meer JT. Optic neuritis heralding varicella zoster virus retinitis in a patient with acquired immunodeficiency syndrome. Ann Neurol. 1998;43(4):534-536.

70. Shayegani A, Odel JG, Kazim M, Hall LS, Bamford N, Schubert H. Varicella-zoster virus retrobulbar optic neuritis in a patient with human immunodeficiency virus. Am J Ophthalmol. 1996;122(4): 586-588.

71. Lee MS, Cooney EL, Stoessel KM, Gariano RF. Varicella zoster virus retrobulbar optic neuritis preceding retinitis in patients with acquired immune deficiency syndrome. Ophthalmology. 1998; 105(3):467-471.

72. Cacciatori M, Ling CS, Dhillon B. Retrobulbar neuritis in a patient with acquired immune deficiency syndrome. Acta Ophthalmol Scand. 1996;74(2):194-196.

73. Liu JZ, Brown P, Tselis A. Unilateral retrobulbar optic neuritis due to varicella zoster virus in a patient with AIDS: a case report and review of the literature. J Neurol Sci. 2005;237(1-2):97-101.

74. Bert RJ, Samawareerwa R, Melhem ER. CNS MR and CT findings associated with a clinical presentation of herpetic acute retinal necrosis and herpetic retrobulbar optic neuritis: five HIV-infected and one non-infected patients. AJNR Am J Neuroradiol. 2004; 25(10): 1722-1729.

75. Franco-Paredes C, BellehemeurT, MerchantA, Sanghi P, DiazGranados C, Rimland D. Aseptic meningitis and optic neuritis preceding varicellazoster progressive outer retinal necrosis in a patient with AIDS. AIDS. 2002;16(7):1045-1049.

76. Litoff D, Catalano RA. Herpes zoster optic neuritis in human immunodeficiency virus infection. Arch Ophthalmol. 1990;108(6): 782-783.

77. Friedman RF, Ganiban GJ, Liss RA, Friedel SD. Ocular syphilis and neurosyphilis in a patient with human immunodeficiency virus infection. Md Med J. 1995;44(4):284-288.

78. Carter JB, Hamill RJ, Matoba AY. Bilateral syphilitic optic neuritis in a patient with a positive test for HIV. Case report. Arch Ophthalmol. 1987;105(11):1485-1486.

79. Passo MS, Rosenbaum JT. Ocular syphilis in patients with human immunodeficiency virus infection. Am J Ophthalmol. 1988; 106(1):1-6.

80. McLeish WM, Pulido JS, Holland S, Culbertson WW, Winward K. The ocular manifestations of syphilis in the human immunodeficiency virus type 1-infected host. Ophthalmology. 1990;97(2): 196-203.

81. Li SY, Birnbaum AD, Tessler HH, Goldstein DA. Posterior syphilitic uveitis: clinical characteristics, co-infection with HIV, response to treatment. Jpn J Ophthalmol. 2011;55(5):486-494. 
82. Joyce PW, Haye KR, Ellis ME. Syphilitic retinitis in a homosexual man with concurrent HIV infection: case report. Genitourin Med. 1989;65(4):244-247.

83. Konjevic-Pernar S, Bednar I, Novak-Laus K, Petric-Vickovic I, Mandic Z. Bilateral optic neuritis as initial manifestation of neurosyphilis in a HIV-positive patient. Acta Clin Croat. 2008; 47(2):97-100.

84. Zaidman GW. Neurosyphilis and retrobulbar neuritis in a patient with AIDS. Ann Ophthalmol. 1986;18(9):260-261.

85. Zambrano W, Perez GM, Smith JL. Acute syphilitic blindness in AIDS. J Clin Neuroophthalmol. 1987;7(1):1-5.

86. Tomsak RL, Lystad LD, Katirji MB, Brassel TC. Rapid response of syphilitic optic neuritis to posterior sub-tenon's steroid injection. J Clin Neuroophthalmol. 1992;12(1):6-7; discussion 8-9.

87. Halperin LS. Neuroretinitis due to seronegative syphilis associated with human immunodeficiency virus. J Clin Neuroophthalmol. 1992;12(3):171-172.

88. Basta MS, Sankar KN, Dayan M. Unilateral syphilitic perioptic neuritis in a patient coinfected with human immunodeficiency virus type 1 . Sex Transm Infect. 2007;83(3):183-184.

89. Meehan K, Rodman J. Ocular perineuritis secondary to neurosyphilis. Optom Vis Sci. 2010;87(10):E790-E796.

90. Smith JL, Byrne SF, Cambron CR. Syphiloma/gumma of the optic nerve and human immunodeficiency virus seropositivity. J Clin Neuroophthalmol. 1990;10(3):175-184.

91. Currie J. AIDS and neuro-ophthalmology. Curr Opin Ophthalmol. 1995;6(6):34-40.

92. Kestelyn P, Taelman H, Bogaerts J, et al. Ophthalmic manifestations of infections with Cryptococcus neoformans in patients with the acquired immunodeficiency syndrome. Am J Ophthalmol. 1993;116(6):721-727.

93. De Socio GV, Bernini L, Menduno P, Pitzurra L, Leone F, Baldelli F. Monolateral visual loss due to cryptococcal meningitis. J Int Assoc Physicians AIDS Care (Chic). 2011;10(2):76-78.

94. Cohen DB, Glasgow BJ. Bilateral optic nerve cryptococcosis in sudden blindness in patients with acquired immune deficiency syndrome. Ophthalmology. 1993;100(11):1689-1694.

95. Lipson BK, Freeman WR, Beniz J, et al. Optic neuropathy associated with cryptococcal arachnoiditis in AIDS patients. Am J Ophthalmol. May 15, 1989;107(5):523-527.

96. Golnik KC, Newman SA, Wispelway B. Cryptococcal optic neuropathy in the acquired immune deficiency syndrome. J Clin Neuroophthalmol. 1991;11(2):96-103.

97. Corti M, Solari R, Cangelosi D, et al. Sudden blindness due to bilateral optic neuropathy associated with cryptococcal meningitis in an AIDS patient. Rev Iberoam Micol. 2010;27(4): 207-209.

98. Specht CS, Mitchell KT, Bauman AE, Gupta M. Ocular histoplasmosis with retinitis in a patient with acquired immune deficiency syndrome. Ophthalmology. 1991;98(9):1356-1359.

99. Yau TH, Rivera-Velazquez PM, Mark AS, et al. Unilateral optic neuritis caused by Histoplasma capsulatum in a patient with the acquired immunodeficiency syndrome. Am J Ophthalmol. 1996; 121(3):324-326.

100. Farthing CF, Howard RS, Thin RN. Papillitis and hepatitis B. Br Med $J$ (Clin Res Ed). 1986;292(6537):1712.

101. Wong MT, Dolan MJ, Lattuada CP Jr, et al. Neuroretinitis, aseptic meningitis, and lymphadenitis associated with Bartonella (Rochalimaea) henselae infection in immunocompetent patients and patients infected with human immunodeficiency virus type 1. Clin Infect Dis. Aug 1995;21(2):352-360.

102. Lee BL, Holland GN, Glasgow BJ. Chiasmal infarction and sudden blindness caused by mucormycosis in AIDS and diabetes mellitus. Am J Ophthalmol. 1996;122(6):895-896.

103. Pepose JS, Holland GN, Nestor MS, Cochran AJ, Foos RY. Acquired immune deficiency syndrome. Pathogenic mechanisms of ocular disease. Ophthalmology. 1985;92(4):472-484.

104. Ofner S, Baker RS. Visual loss in cryptococcal meningitis. J Clin Neuroophthalmol. 1987;7(1):45-48.
105. Laverda AM, Ruga E, Pagliaro A, Pinello ML, Giaquinto C. Intracranial hypertension and cryptococcal meningitis in a girl with AIDS. Brain Dev. 1996;18(4):330-331.

106. Johnston SR, Corbett EL, Foster O, Ash S, Cohen J. Raised intracranial pressure and visual complications in AIDS patients with cryptococcal meningitis. J Infect. 1992;24(2):185-189.

107. Majumder S, Mandal SK, Bandyopadhyay D. Prognostic markers in AIDS-related cryptococcal meningitis. J Assoc Physicians India. 2011;59:152-154.

108. Battu RR, Biswas J, Jayakumar N, Madhavan HN, Kumarsamy N, Solomon S. Papilloedema with peripapillary retinal haemorrhages in an acquired immunodeficiency syndrome (AIDS) patient with cryptococcal meningitis. Indian J Ophthalmol. 2000;48(1): 47-49.

109. Good CB, Leeper HF. Profound papilledema due to cryptococcal meningitis in acquired immunodeficiency syndrome: successful treatment with fluconazole. South Med J. 1991;84(3): 394-396.

110. Cooper S, Razvi S, Alani A, Winter A, Browne B, Metcalfe R. Syphilis presenting with headache and papilloedema. BMJ Case Rep. 2009.

111. Balo KP, Amoussou YP, Bechetoille A, et al. Cytomegalovirus retinitis and ocular complications in AIDS patients in Togo. J Fr Ophtalmol. 1999;22(10):1042-1046.

112. Castro-Rebollo M, Vleming EN, Drake-Rodriguez P, Benitez-Herreros J, Perez-Rico C. Primary cerebral lymphoma diagnosed by the ophthalmologist. Arch Soc Esp Oftalmol. 2010;85(1):35-37.

113. Jabs DA. Ocular manifestations of HIV infection. Trans Am Ophthalmol Soc. 1995;93:623-683.

114. Garrity JA, Herman DC, Imes R, Fries P, Hughes CF, Campbell RJ. Optic nerve sheath decompression for visual loss in patients with acquired immunodeficiency syndrome and cryptococcal meningitis with papilledema. Am J Ophthalmol. 1993;116(4): 472-478.

115. Milman T, Mirani N, Turbin RE. Optic nerve sheath fenestration in cryptococcal meningitis. Clin Ophthalmol. 2008;2(3): 637-639.

116. Lee LC, Howes EL, Bhisitkul RB. Systemic non-Hodgkin's lymphoma with optic nerve infiltration in a patient with AIDS. Retina. 2002; 22(1):75-79.

117. Lee AG, Tang RA, Roberts D, Schiffman JS, Osborne A. Primary central nervous system lymphoma involving the optic chiasm in AIDS. J Neuroophthalmol. 2001;21(2):95-98.

118. Zimmer C, Nieuwenhuis I, Danisevskis M, Spiegel H, Hansen LL. Sudden blindness in an AIDS patient. Simultaneous infection with cytomegalovirus and herpes simplex viruses and development of malignant non-Hodgkin lymphoma. Klin Monbl Augenheilkd. 1991; 199(1):48-52.

119. Brack MJ, Cleland PG, Owen RI, Allen ED. Anterior ischaemic optic neuropathy in the acquired immune deficiency syndrome. $\mathrm{Br} \mathrm{Med} J$ (Clin Res Ed). 1987;295(6600):696-697.

120. Warner JE, Ries KM. Optic neuropathy in a patient with AIDS. J Neuroophthalmol. 2001;21(2):92-94.

121. Gasnault J, Roux FX, Vedrenne C. Cerebral astrocytoma in association with HIV infection. J Neurol Neurosurg Psychiatry. 1988;51(3): 422-424.

122. Margo CE, Hamed LM. Ocular syphilis. Surv Ophthalmol. 1992; 37(3):203-220.

123. Berger JR, Kaszovitz B, Post MJ, Dickinson G. Progressive multifocal leukoencephalopathy associated with human immunodeficiency virus infection. A review of the literature with a report of sixteen cases. Ann Intern Med. 1987;107(1):78-87.

124. Slavin ML, Mallin JE, Jacob HS. Isolated homonymous hemianopsia in the acquired immunodeficiency syndrome. Am J Ophthalmol. 1989;108(2):198-200.

125. Gillespie SM, Chang Y, Lemp G, et al. Progressive multifocal leukoencephalopathy in persons infected with human immunodeficiency virus, San Francisco, 1981-1989. Ann Neurol. 1991;30(4): 597-604.

126. Singer EJ, Stoner GL, Singer P, et al. AIDS presenting as progressive multifocal leukoencephalopathy with clinical response to zidovudine. Acta Neurol Scand. 1994;90(6):443-447. 
127. Wein F, Francis GS, Gans MS, Connolly WE, Burnier MN Jr. Neuro-ophthalmic findings in progressive multifocal leukoencephalopathy. Can J Ophthalmol. 1998;33(5):270-275.

128. Shapiro RA, Mullane KM, Camras L, Flowers C, Sutton S. Clinical and magnetic resonance imaging regression of progressive multifocal leukoencephalopathy in an AIDS patient after intensive antiretroviral therapy. J Neuroimaging. 2001;11(3):336-339.

129. Diller R, Thompson K. Visual loss secondary to acquired immunodeficiency virus-related progressive multifocal leukoencephalopathy demonstrating clinical improvement with highly active antiretroviral therapy. Optometry. 2007;78(2):63-70.

130. Geier SA, Nohmeier C, Lachenmayr BJ, Klauss V, Goebel FD. Deficits in perimetric performance in patients with symptomatic human immunodeficiency virus infection or acquired immunodeficiency syndrome. Am J Ophthalmol. 1995;119(3):335-344.

131. Plummer DJ, Sample PA, Arevalo JF, et al. Visual field loss in HIVpositive patients without infectious retinopathy. Am J Ophthalmol. 1996;122(4):542-549.

132. Goldbaum MH, Kozak I, Hao J, et al. Pattern recognition can detect subtle field defects in eyes of HIV individuals without retinitis under HAART. Graefes Arch Clin Exp Ophthalmol. 2011;249(4): 491-498.

133. Shah KH, Holland GN, Yu F, Van Natta M, Nusinowitz S. Contrast sensitivity and color vision in HIV-infected individuals without infectious retinopathy. Am J Ophthalmol. 2006;142(2):284-292.

134. Mueller AJ, Plummer DJ, Dua R, et al. Analysis of visual dysfunctions in HIV-positive patients without retinitis. Am J Ophthalmol. 1997; 124(2):158-167.

135. Geier SA, Kronawitter U, Bogner JR, et al. Impairment of colour contrast sensitivity and neuroretinal dysfunction in patients with symptomatic HIV infection or AIDS. Br J Ophthalmol. 1993; 77(11):716-720.

136. Kozak LC, Bullimore MA. Visual changes in human immuno-deficiency virus infection. Optom Vis Sci. 1994;71(9):557-561.

137. Quiceno JI, Capparelli E, Sadun AA, et al. Visual dysfunction without retinitis in patients with acquired immunodeficiency syndrome. Am J Ophthalmol. 1992;113(1):8-13.

138. Malessa R, Agelink MW, Diener HC. Dysfunction of visual pathways in HIV-1 infection. J Neurol Sci. May 1995;130(1):82-87.

139. Pierelli F, Soldati G, Zambardi P, et al. Electrophysiological study (VEP, BAEP) in HIV-1 seropositive patients with and without AIDS. Acta Neurol Belg. 1993;93(2):78-87.

140. Iragui VJ, Kalmijn J, Plummer DJ, Sample PA, Trick GL, Freeman WR. Pattern electroretinograms and visual evoked potentials in HIV infection: evidence of asymptomatic retinal and postretina impairment in the absence of infectious retinopathy. Neurology. 1996;47(6):1452-1456.

141. Farnarier G, Somma-Mauvais H. Multimodal evoked potentials in HIV infected patients. Electroencephalogr Clin Neurophysiol Suppl. 1990;41:355-369.

142. Mahadevan A, Satishchandra P, Prachet KK, et al. Optic nerve axonal pathology is related to abnormal visual evoked responses in AIDS. Acta Neuropathol. 2006;112(4):461-469.

143. Iragui VJ, Kalmijn J, Thal LJ, Grant I. Neurological dysfunction in asymptomatic HIV-1 infected men: evidence from evoked potentials. HNRC Group. Electroencephalogr Clin Neurophysiol. 1994; 92(1):1-10.

144. Honrubia FM, Ferrer E, Torron C, Gonzalez I. Study of the retinal fiber layer in patients with acquired immunodeficiency syndrome. Ger J Ophthalmol. 1994;3(1):1-4.

145. Arantes TE, Garcia CR, Tavares IM, Mello PA, Muccioli C. Relationship between retinal nerve fiber layer and visual field function in human immunodeficiency virus-infected patients without retinitis. Retina. 2012;32(1):152-159.

146. Kozak I, Bartsch DU, Cheng L, Kosobucki BR, Freeman WR. Objective analysis of retinal damage in HIV-positive patients in the HAART era using OCT. Am J Ophthalmol. 2005;139(2): 295-301.
147. Faria EATE, Garcia CR, Mello PA, Muccioli C. Structural and functional assessment in HIV-infected patients using optical coherence tomography and frequency-doubling technology perimetry. $\mathrm{Am} \mathrm{J}$ Ophthalmol. 2010;149(4):571-576. e572.

148. Kalyani PS, Holland GN, Fawzi AA, Arantes TE, Yu F, Sadun AA. Association between retinal nerve fiber layer thickness and abnormalities of vision in people with human immunodeficiency virus infection. Am J Ophthalmol. 2012;153(4):734-742, 742. e731.

149. Hamed LM, Schatz NJ, Galetta SL. Brainstem ocular motility defects and AIDS. Am J Ophthalmol. 1988;106(4):437-442.

150. Tervo T, Elovaara I, Karli H, et al. Abnormal ocular motility as early sign of CNS involvement in HIV infection. Lancet. 1986; 2(8505):512.

151. Teschke RS. A tetrad of neurologic signs sensitive to early human immunodeficiency virus brain disease. Arch Neurol. 1987; 44(7):693.

152. Sweeney JA, Palumbo DR, Halper JP, Shear MK. Pursuit eye movement dysfunction in obsessive-compulsive disorder. Psychiatry Res. 1992;42(1):1-11.

153. Currie J, Benson E, Ramsden B, Perdices M, Cooper D. Eye movement abnormalities as a predictor of the acquired immunodeficiency syndrome dementia complex. Arch Neurol. 1988;45(9):949-953.

154. Nguyen N, Rimmer S, Katz B. Slowed saccades in the acquired immunodeficiency syndrome. Am J Ophthalmol. 1989;107(4):356-360.

155. Merrill PT, Paige GD, Abrams RA, Jacoby RG, Clifford DB. Ocular motor abnormalities in human immunodeficiency virus infection. Ann Neurol. 1991;30(2):130-138.

156. Johnston JL, Miller JD, Nath A. Ocular motor dysfunction in HIV1- infected subjects: a quantitative oculographic analysis. Neurology. 1996;46(2):451-457

157. Friedman DI, Feldon SE. Eye movements in acquired immunodeficiency syndrome. Arch Neurol. 1989;46(8):841.

158. Rehman F, Mehler MF. Reverse ocular dipping. Neurology. 1988;38(3):506.

159. Tagliati M, Simpson D, Morgello S, Clifford D, Schwartz RL, Berger JR. Cerebellar degeneration associated with human immunodeficiency virus infection. Neurology. 1998;50(1):244-251.

160. Scott KM, Parker F, Heckmann JM. Opsoclonus-myoclonus syndrome and HIV-infection. J Neurol Sci. 2009;284(1-2):192-195.

161. Ayarza A, Parisi V, Altclas J, et al. Opsoclonus-myoclonus-ataxia syndrome and HIV seroconversion. J Neurol. 2009; 256(6):1024-1025.

162. Kanjanasut N, Phanthumchinda K, Bhidayasiri R. HIV-related opsoclonus-myoclonus-ataxia syndrome: report on two cases. Clin Neurol Neurosurg. 2010;112(7):572-574.

163. van Toorn R, Rabie H, Warwick JM. Opsoclonus-myoclonus in an HIV-infected child on antiretroviral therapy-possible immune reconstitution inflammatory syndrome. Eur J Paediatr Neurol. 2005; 9(6):423-426.

164. Garcia-Morales I, Porta-Etessam J, Saiz-Diaz R, et al. Opsoclonusmyoclonus in a patient with AIDS: a good response to treatment with IV immunoglobulins. Rev Neurol. 1999;29(12): 1346-1348.

165. Antworth MV, Beck RW. Third nerve palsy as a presenting sign of acquired immune deficiency syndrome. J Clin Neuroophthalmol. 1987;7(3):125-128.

166. Kure K, Harris C, Morin LS, Dickson DW. Solitary midbrain toxoplasmosis and olivary hypertrophy in a patient with acquired immunodeficiency syndrome. Clin Neuropathol. 1989;8(1): $35-40$.

167. Sherman MD, Allinson RW, Obbens EA, Darragh JM, Simons KB. Internuclear ophthalmoplegia in acquired immunodeficiency syndrome. Ann Ophthalmol. 1989;21(8):294-295.

168. Humphry RC, Weber JN, Marsh RJ. Ophthalmic findings in a group of ambulatory patients infected by human immunodeficiency virus (HIV): a prospective study. Br J Ophthalmol. 1987;71(8): 565-569

169. Fuller GN, Guiloff RJ, Scaravilli F, Harcourt-Webster JN. Combined HIV-CMV encephalitis presenting with brainstem signs. J Neurol Neurosurg Psychiatry. 1989;52(8):975-979. 
170. Laskin OL, Stahl-Bayliss CM, Morgello S. Concomitant herpes simplex virus type 1 and cytomegalovirus ventriculoencephalitis in acquired immunodeficiency syndrome. Arch Neurol. 1987;44(8):843-847.

171. Horoupian DS, Pick P, Spigland I, et al. Acquired immune deficiency syndrome and multiple tract degeneration in a homosexual man. Ann Neurol. 1984;15(5):502-505.

172. Masdeu JC, Small CB, Weiss L, Elkin CM, Llena J, Mesa-Tejada R. Multifocal cytomegalovirus encephalitis in AIDS. Ann Neurol. 1988; 23(1):97-99

173. Jacobson MA, Mills J, Rush J, et al. Failure of antiviral therapy for acquired immunodeficiency syndrome-related cytomegalovirus myelitis. Arch Neurol. 1988;45(10):1090-1092.

174. Moulignier A, Baudrimont M, Martin-Negrier ML, Mikol J, Lapresle C, Dupont B. Fatal brain stem encephalitis due to herpes simplex virus type 1 in AIDS. J Neurol. 1996;243(6):491-493.

175. Behar R, Wiley C, McCutchan JA. Cytomegalovirus polyradiculoneuropathy in acquired immune deficiency syndrome. Neurology. 1987; 37(4):557-561.

176. Khadem M, Kalish SB, Goldsmith J, et al. Ophthalmologic findings in acquired immune deficiency syndrome (AIDS). Arch Ophthalmol. 1984;102(2):201-206.

177. Griffin DK, Shriver ME, Hauser R. Parinaud's syndrome as the initial manifestation of acquired immunodeficiency syndrome. J Neuroimaging. 1994;4(2):113-114.

178. Kitthaweesin K. Upward gaze paralysis as the initial manifestation of HIV-infected patient: a case report. J Med Assoc Thai. 2002; 85(6):728-732.

179. Daras M, Koppel BS, Samkoff L, Marc J. Brainstem toxoplasmosis in patients with acquired immunodeficiency syndrome. J Neuroimaging. 1994;4(2):85-90.

180. Levy RM, Bredesen DE. Central nervous system dysfunction in acquired immunodeficiency syndrome. J Acquir Immune Defic Syndr. 1988;1(1):41-64.

181. Helweg-Larsen S, Jakobsen J, Boesen F, Arlien-Soborg P. Neurological complications and concomitants of AIDS. Acta Neurol Scand. 1986; 74(6):467-474.

182. Hughes PJ, McLean KA, Lane RJ. Cranial polyneuropathy and brainstem disorder at the time of seroconversion in HIV infection. Int J STD AIDS. 1992;3(1):60-61.

183. Mohan S, Ahmed SI, Alao OA, Schliep TC. A case of AIDS associated cryptococcal meningitis with multiple cranial nerve neuropathies. Clin Neurol Neurosurg. 2006;108(6):610-613.

184. Snider WD, Simpson DM, Nielsen S, Gold JW, Metroka CE, Posner JB. Neurological complications of acquired immune deficiency syndrome: analysis of 50 patients. Ann Neurol. 1983;14(4):403-418.

185. Grassi MA, Lee AG. Lymphomatous meningitis of the Burkitt type presenting with multiple cranial neuropathies. Am J Ophthalmol. 2002;133(3):424-425.

186. Karna S, Biswas J, Kumarasamy N, Sharma P, Solomon S. Multiple cranial nerve palsy in an HIV-positive patient. Indian J Ophthalmol. 2001;49(2):118-120.

187. Farkash AE, Maccabee PJ, Sher JH, Landesman SH, Hotson G. CNS toxoplasmosis in acquired immune deficiency syndrome: a clinicalpathological-radiological review of 12 cases. J Neurol Neurosurg Psychiatry. 1986;49(7):744-748.

188. Jack MK, Smith T, Collier AC. Oculomotor cranial nerve palsey associated with acquired immunodeficiency syndrome. Ann Ophthalmol. 1984;16(5):460-462.

189. Levy J, Kratz A, Lifshitz T. Burkitt's lymphoma presenting as oculomotor palsy in an hiv-positive patient. Eur J Ophthalmol. 2006;16(1):186-189.

190. Keane JR. Intermittent third nerve palsy with cryptococcal meningitis. J Clin Neuroophthalmol. 1993;13(2):124-126.

191. Moulignier A, Laloum L, Chauveau E, Gout O, Rozenbaum W. HIV-1 related ischaemic trochlear nerve palsy. J Neurol. 2003;250(1): 108-109.
192. Sadun F, De Negri AM, Santopadre P, Pivetti Pezzi P. Bilateral trochlear nerve palsy associated with cryptococcal meningitis in human immunodeficiency virus infection. J Neuroophthalmol. 1999; 19(2):118-119.

193. Maclean H, Ironside J, Dhillon B. Acquired immunodeficiency syndrome-related primary central nervous system lymphoma. Arch Ophthalmol. 1994;112(2):269-271.

194. Navia BA, Petito CK, Gold JW, Cho ES, Jordan BD, Price RW. Cerebral toxoplasmosis complicating the acquired immune deficiency syndrome: clinical and neuropathological findings in 27 patients. Ann Neurol. 1986;19(3):224-238.

195. Nkomazana O, Tshitswana D. Ocular complications of HIV infection in sub-Sahara Africa. Curr HIV/AIDS Rep. 2008;5(3):120-125.

196. Levy JH, Liss RA, Maguire AM. Neurosyphilis and ocular syphilis in patients with concurrent human immunodeficiency virus infection. Retina. 1989;9(3):175-180.

197. Morales C, Tachauer A. Gradenigo syndrome in a human immunodeficiency virus-positive patient. Arch Intern Med. 1997; 157(18):2149.

198. Linstrom CJ, Pincus RL, Leavitt EB, Urbina MC. Otologic neurotologic manifestations of HIV-related disease. Otolaryngol Head Neck Surg. 1993;108(6):680-687.

199. Ogunseyinde AO, Familusi JB. HIV-assocated lymphoma: a case report. Afr J Med Med Sci. 2002;31(3):283-285.

200. Belec L, Gherardi R, Georges AJ, et al. Peripheral facial paralysis and HIV infection: report of four African cases and review of the literature. J Neurol. 1989;236(7):411-414.

201. Abboud O, Saliba I. Isolated bilateral facial paralysis revealing AIDS: a unique presentation. Laryngoscope. 2008;118(4):580-584.

202. Piluso S, Ficarra G, Gaglioti D, Pierleoni F. Peripheral facial paralysis and HIV infection. Minerva Stomatol. 1991;40(7-8): 495-498.

203. Brown MM, Thompson A, Goh BT, Forster GE, Swash M. Bell's palsy and HIV infection. J Neurol Neurosurg Psychiatry. 1988;51(3):425-426.

204. Bosel J, Klingebiel R, Schielke E. HIV-associated neurosyphilis mimicking acoustic neurinoma. J Neurol. 2006;253(2): 250-252.

205. Sasaki MG, Leite PG, Leite AG, de Almeida SM. Bilateral peripheral facial palsy secondary to lymphoma in a patient with HIV/ AIDS: a case report and literature review. Braz J Infect Dis. 2002; 6(1):50-54.

206. Katz DA, Berger JR. Neurosyphilis in acquired immunodeficiency syndrome. Archives of neurology. 1989;46(8):895-898.

207. Barreira Junior AK, Moura FC, Monteiro ML. Bilateral cavernous sinus non-Hodgkin's lymphoma as the presenting sign of acquired immunodeficiency syndrome: case report. Arq Bras Oftalmol. 2011;74(2):130-131.

208. Verma R, Dhamija R, Leeburg WT, Rafi M, Loehrke ME. Burkitt lymphoma presenting as ptosis in a man with human immunodeficiency virus. Am J Med Sci. 2011;342(5):427-428.

209. Saxena R, Phuljhele S, Aalok L, et al. A rare case of orbital apex syndrome with herpes zoster ophthalmicus in a human immunodeficiency virus-positive patient. Indian J Ophthalmol. 2010; 58(6):527-530.

210. Gross FJ, Waxman JS, Rosenblatt MA, Tabibzadeh SS, Solodnik P. Eosinophilic granuloma of the cavernous sinus and orbital apex in an HIV-positive patient. Ophthalmology. 1989;96(4):462-467.

211. Johnson TE, Casiano RR, Kronish JW, Tse DT, Meldrum M, Chang W. Sino-orbital aspergillosis in acquired immunodeficiency syndrome. Arch Ophthalmol. 1999;117(1):57-64.

212. Pfeffer G, Cote HC, Montaner JS, Li CC, Jitratkosol M, Mezei MM. Ophthalmoplegia and ptosis: mitochondrial toxicity in patients receiving HIV therapy. Neurology. 2009;73(1):71-72.

213. Dinges WL, Witherspoon SR, Itani KM, Garg A, Peterson DM. Blepharoptosis and external ophthalmoplegia associated with longterm antiretroviral therapy. Clin Infect Dis. 2008;47(6): 845-852.

214. Silkiss RZ, Lee H, Gills Ray VL. Highly active antiretroviral therapyassociated ptosis in patients with human immunodeficiency virus. Arch Ophthalmol. 2009;127(3):345-346. 
215. Cerny R, Rozsypal H, Kozner P, Machala L. Bilateral Holmes-Adie syndrome as an early manifestation of the HIV neuropathy. Neurol Sci. 2010;31(5):661-663.

216. Harada H, Tamaoka A, Yoshida H, et al. Horner's syndrome associated with mononeuritis multiplex due to cytomegalovirus as the initial manifestation in a patient with AIDS. J Neurol Sci. 1998;154(1):91-93.

217. Maclean H, Dhillon B. Pupil cycle time and human immunodeficiency virus (HIV) infection. Eye (Lond). 1993;7(Pt 6):785-786.

218. Kaleem MA, Ramsahai S, Del Fierro K, et al. Ocular findings in human immunodeficiency virus patients in Washington, DC. International Ophthalmology. 2012;32(2):145-151.
219. Jabs DA, Van Natta ML, Holbrook JT, Kempen JH, Meinert CL, Davis MD. Longitudinal study of the ocular complications of AIDS: 1. Ocular diagnoses at enrollment. Ophthalmology. 2007;114(4):780-786.

220. Whitley RJ, Jacobson MA, Friedberg DN, et al. Guidelines for the treatment of cytomegalovirus diseases in patients with AIDS in the era of potent antiretroviral therapy: recommendations of an international panel. International AIDS Society-USA. Archives of Internal Medicine. 1998;158(9):957-969.

Neurobehavioral HIV Medicine

\section{Publish your work in this journal}

Neurobehavioral HIV Medicine is an international, peer-reviewed, open access journal focusing on advances in research in HIV/ AIDS, with specific reference to the neurological, psychiatric and behavioral consequences of the disease, concomitant infections and specific antiretroviral therapy. The manuscript

\section{Dovepress}

management system is completely online and includes a very quick and fair peer-review system, which is all easy to use. Visit http://www.dovepress.com/testimonials.php to read real quotes from published authors.

Submit your manuscript here: http://www.dovepress.com/journal-of-neurobehavioral-hiv-medicine-journal 